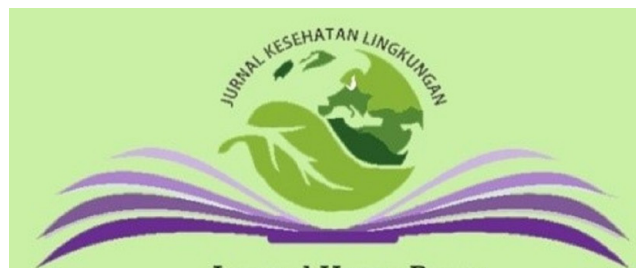

Journal Home Page:

https://e-journal.unair.ac.id/JKL

\section{Jurnal Kesehatan Lingkungan}

Vol. 13 No. 4

DOI: $10.20473 /$ jkl.v13i4.2021.204-210

ISSN: 1829 - 7285

E-ISSN: 2040 - 881X

\title{
HEALTH RISK DUE TO CARBAMATE EXPOSURE IN COMMUNITIES AROUND PADDY FIELD AREAS
}

\begin{abstract}
Maksuk Maksuk ${ }^{1 *}$, Sherli Shobur ${ }^{1}$, Suzanna
Suzanna ${ }^{2}$

${ }^{1}$ Department of Environmental Health, Health

Polytechnic Palembang Ministry of Health, South

Sumatera 30121, Indonesia.

${ }^{2}$ Center for Environmental Health Engineering and

Disease Control Palembang, South Sumatera 30961, Indonesia.
\end{abstract}

\section{Corresponding Author:}

*)maksuk@poltekkespalembang.ac.id

\section{Article Info}

Submitted

In reviewed

Accepted

17 August 2021

1 September 2021

Available Online

22 September 2021

31 October 2021

Keywords : Health risk, Carbamate, Paddy fields area

Published by Fakultas Kesehatan Masyarakat Universitas Airlangga

\begin{abstract}
Introduction: Carbamate is one of the most widely used pesticides in paddy field areas, which causes environmental pollution and human health problems. Therefore, this study aims to analyze the health risks of carbamate exposure in communities around paddy fields areas. Methods: This was an observational analysis study conducted using the health risk assessment approach. There were 20 samples of waterway streams from 10 sites observed in the morning (at high tide) and evening (at low tide) taken using a grab sampling method. The parameters of the waterway streams river, such as $\mathrm{pH}$ and temperature, were measured on-site using a $\mathrm{pH}$ meter and portable thermometer, while the carbamate concentration was analysed in the laboratory using High-Performance Liquid Chromatography (HPLC). Results and Discussion: The active ingredients of carbamate pesticides that observed as follows: aldicarb $(0-0.05 \mathrm{mg} / \mathrm{l})$, carbaryl $(0-0.01 \mathrm{mg} / \mathrm{l})$, carbofuran $(0-0.005$ $\mathrm{mg} / \mathrm{l})$, and propoxur $(0-0.001 \mathrm{mg} / \mathrm{l})$. While the $\mathrm{pH}(6.4-7.5)$ and temperature $(22.1$ $-32.4 o C)$. The potential exposure of Aldicarb in grown-up and kids were 0.042 and $0.077 \mathrm{mg} / \mathrm{kg}$ bodyweight-day, respectively. Furthermore, the potential exposure of carbofuran in Grown-ups and kids were 0.004 and $0.01 \mathrm{mg} / \mathrm{kg}$ bodyweight-day, respectively. Only the carbofuran exposure in kids has a rate of $R Q>1$, which is unsafe or can cause non-carcinogenic effects in the next 30 years. Conclusion: Although the carbamate concentrations in waterway streams around paddy field areas were below the quality standard, it is not safe. Therefore, it is necessary to carry out risk management and communication with local policymakers.
\end{abstract}

\section{INTRODUCTION}

Pesticides compounds have been used widely in the agricultural sector to kill pests, weeds and increase harvests productivity (1-5). The use of pesticides is the basis of agriculture intensification developed in the middle of the $20^{\text {th }}$ century (6-7) to improve the productivity and quality of farming commodities $(4,8-9)$. Based on the results in China, the total pesticides emissions increased from 165.47 tons in 2004 to 179.77 tons in 2017 (10).

Currently, the pesticides mostly used in the agricultural sector include organophosphate and carbamate (11). In Indonesia, approximately 3,207 pesticideshave beenlegallyregistered(12-14). Moreover, carbamate is structurally and mechanistically similar to organophosphate and is $\mathrm{N}$-methyl Carbamate derived from carbamic acid that will inhibit acetylcholinesterase at neuronal synapses and neuromuscular junction. These pesticides are effective due to their ability to inhibit acetylcholinesterase in the nervous system and other esterases (15-16).

In developing countries, pesticide poisoning and toxicity incidences gradually increase due to acetylcholinesterase inhibition (17) and have become a public health problem (18). Meanwhile, the poisoning was most common among farmers, farming families, and communities around agricultural areas (19). A study in China stated that organophosphate and carbamate insecticides were the cause of most poisonings in children amount 1130, which lead to 34 deaths (20).

The overuse and misuse of pesticides contaminate the environment, soil, and water media (2). Although carbamate is very persistent in the environment and contains highly soluble compounds in water (16), the contamination in the surface water is caused by improper application and inappropriate spraying, sewage of rice milling factories, and other agricultural activities $(2,9)$.

Based on a previous study, the carbamate concentration was detected in Bangladesh's Savar and Dhamrai Upazilas waterways (21). However, carbofuran residues were detected in water Kalisat River, Malang Regency (22-23). It is showed that the presence of carbamate pesticides in the water basin, river, and surface water varies due to aerial spraying, erosion, sewage from factories, wastewater disposal, and agriculture runoff (1-2). 
Carbamate is widely used to kill insects in South Sumatra's agricultural areas, including Pegayut Village, Ogan Ilir Regency. Pegayut is among the villages in Pemulutan District, along the waterway streams in the rice farming area. The river is the primary source of clean water for Pegayut Village communities and the source of irrigation for agricultural lands. The most widely used pesticides in the rice farming area of Pegayut Village are organophosphates and carbamate of various types to kill insects. These pesticides enter and contaminate the village's waterway streams through agricultural activities, rice milling factories, and equipment washing after application. Therefore, there is a need to monitor the presence of carbamate in the waterway streams in agricultural areas through risk assessment and management. This is because water contamination from exposure to pesticides is harmful to farmers, families, communities, and the environment (24). Furthermore, health risk assessment is needed for the early diagnosis of diseases caused by pesticides exposure, health surveillance, and reporting systems for worker protection in terms of safety and health in the agriculture area (5). The required health risk assessment for the estimated values for hazard quotient $(\mathrm{HQ})$ and hazard index $(\mathrm{HI})$ for non-carcinogenic risk was below the targeted value, which indicated no non-carcinogenic risk through dermal contact and non-intentional ingestion of water (25).

In Indonesia, the environmental health risk assessment method has existed since 2012, even though the application is still not optimal (26). Although environmental health is an essential program at the public health center, the health risk assessment program has not been carried out optimally, especially studies on pesticides exposure in waterway streams used by communities around paddy field areas. Therefore, this study aims to analyze the health risks of carbamate exposure in waterway streams used by communities around paddy fields.

\section{METHODS}

This observational study was conducted at a residential area along waterway streams around paddy field areas in Pegayut village, Pemulutan, Ogan llir, which used the health risk assessment approach. The study was conducted from October to December at Pegayut Village Pemulutan, Ogan Ilir Regency. Furthermore, 20 water samples from 10 waterway streams would be taken in the morning (at high tide) and evening (at low tide). These samples were collected using the grab sampling method at a depth of $30 \mathrm{~cm}$ from the surface of the waterway streams (27) by BTKLPP Palembang officers and stored in a cold box before sending to the laboratory. Before being analyzed at the laboratory, all samples were saved in a refrigerator at $25^{\circ} \mathrm{C}$. The test parameters include temperature and $\mathrm{pH}$ of the water, which were checked in situ using a portable multifunction analyzer, and the active ingredient Carbamate was examined in the laboratory using HPLC by method 3510 from the US EPA. Meanwhile, the potential dose was calculated using the formula by Louvar and Louvar below (28):

$$
I=\frac{C \times R \times T E \times F E \times D t}{W b \times \operatorname{tavg}}
$$

The explanation of the equation above is as follows:

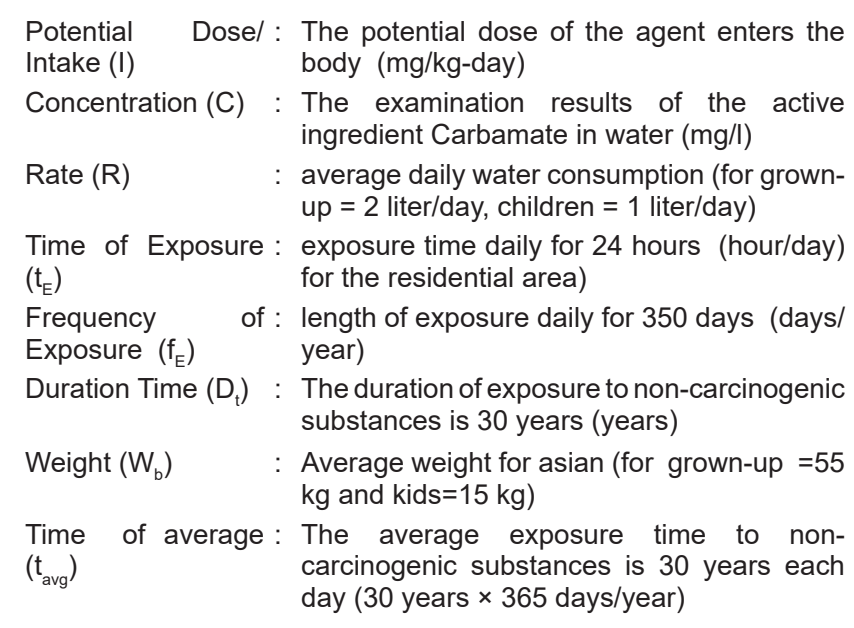

\section{Risk Management}

This study carried out a risk management scenario for carbofuran for kids because the $R Q$ was over 1. The calculation was carried out using the formula by Louvar and Louvar, as shown below (28):

Acceptable Carbofuran Concentration:

$$
\text { Acceptable Concentration }=\frac{I \times W b \times \operatorname{tavg}}{R \times T E \times F E \times D T}
$$

Acceptable Consumption Rate

$$
\text { Acceptable Consumpsion Rate }=\frac{I \times W b \times \text { tavg }}{C \times T E \times F E \times D T}
$$

Acceptable Frequency of Exposure

Acceptable Frequency of Exposure $=\frac{I \times W b \times \operatorname{tavg}}{C \times R \times T E \times D T}$

Acceptable Time of Duration

$$
\text { Acceptable Time of Duration }=\frac{I \times W b \times t a v g}{C \times R \times F E \times T E}
$$

A certificate of appropriate ethics was carried out at the Health Polytechnic Palembang, the number: 499 KEPK/Adm2/X/2020. 


\section{RESULTS}

\section{Hazard Identification}

Hazard identification is the first stage to determine the kinds of active pesticide ingredients and their effect on humans and environmental media (29-30). In Pegayut Village, organophosphates and carbamates are pesticides mostly used in paddy fields areas. In this study, the primary data from water sampling showed the concentrations of carbamate active ingredient, $\mathrm{pH}$, and temperature, as shown in Table 1.

Table 1. The Carbamate Pesticide Levels, Temperature, pH, and The Lenght of The Stream in Rice Fields Zones of Pegayut Waterway Streams

\begin{tabular}{|c|c|c|c|}
\hline Variables & Average & Range & $\begin{array}{c}\text { Maximum } \\
\text { Limit } \\
\text { Values } \\
(\mathbf{3 6 , 3 7 )}\end{array}$ \\
\hline Aldicarb & - & $0-0.05 \mathrm{mg} / 1$ & \multirow{4}{*}{$0.1 \mathrm{mg} / 1$} \\
\hline Carbaryl & - & $0-0.01 \mathrm{mg} / \mathrm{l}$ & \\
\hline Carbofuran & - & $0-0.005 \mathrm{mg} / \mathrm{l}$ & \\
\hline Propoxur & - & $0-0.001$ & \\
\hline Temperature & $29.9^{\circ} \mathrm{C}$ & $22.1-32.4^{\circ} \mathrm{C}$ & $\pm 3^{\circ} \mathrm{C}$ \\
\hline $\mathrm{pH}$ & 6.9 & $6.4-7.5$ & $6-9$ \\
\hline $\begin{array}{l}\text { The length of the } \\
\text { stream to rice field } \\
\text { zones }\end{array}$ & $161.2 \mathrm{~m}$ & $50-500 \mathrm{~m}$ & \\
\hline
\end{tabular}

\section{Dose-Response Assessment of Carbamate Active Ingredient}

The dose-response assessment focused on four active carbamates (Aldicarb, Carbaryl, Carbofuran, and Propoxur), categorized as active ingredients of noncarcinogenic pesticides (31) with the reference dose values of the four active ingredients of Cabamate and can be seen on the IRIS - EPA website.

\section{Exposure Assessment of Carbamate Active Ingredient}

The exposure assessment was carried out after the first and second steps to calculate the potential dose of the risk agent. Exposure assessment determines potential dose or intake value using several variables, including measurement of carbamate concentration, consumption rate, time and frequency of exposure, time duration, bodyweight, time average (32). Furthermore, some variables used to calculate the potential dose are the bodyweight of grown-ups $55 \mathrm{~kg}$ and kids 15 $\mathrm{kg}$, the level of water consumption for grown-ups of approximately 2 liters daily, and kids of almost 1 liter daily with a lifetime exposure of 30 years (32). The potential dose results were different for each carbamate active ingredient, as described in Table 2. The potential dose of Aldicarb obtained more than the reference dosage for both grown-ups and kids, while the potential dose of carbofuran in grown-ups was below and kids was over reference dosage.

Table 2. The Potential Dose of Carbamate Pesticide for Grown-ups and Children in Rice Fields Zones of Pegayut Waterway Streams

\begin{tabular}{lccc}
\hline \multirow{2}{*}{$\begin{array}{c}\text { Active } \\
\text { Ingredient }\end{array}$} & $\begin{array}{c}\text { Reference Dose } \\
(\mathbf{m g} / \text { kg-day) }\end{array}$ & \multicolumn{2}{c}{$\begin{array}{c}\text { Potential Dose } \\
(\mathbf{m g} / \mathbf{k g}-\mathbf{d a y})\end{array}$} \\
\cline { 3 - 4 } & & Grown-ups & Children \\
\hline Aldicarb & 0.001 & 0.042 & 0.077 \\
\hline Carbaryl & 0.1 & 0.008 & 0.015 \\
\hline Carbofuran & 0.005 & 0.004 & 0.01 \\
\hline Propoxur & 0.004 & 0.001 & 0.002 \\
\hline
\end{tabular}

\section{Risk Characterization of Carbamate Active Ingredient}

$\mathrm{RQ}$ (Risk Quotient) is estimated by dividing the potential dose with the reference dosage of Carbamate active ingredients. Based on the results, the $R Q$ of Carbamate active ingredient in waterway streams was less than 1 for grown-ups, while RQ of Carbofuran for kids was over 1. This showed that Carbofuran in waterway streams was risky for kids. Furthermore, the total $R Q$ of Carbamate active ingredient in waterway streams for grown-ups and kids was over 1 . The $R Q$ results of Carbamate active ingredient in waterway streams river were different, as described in Table 3.

Table 3. The RQ (Risk Quotient) and RQ Total Calculation Results of Carbamate Active Ingredient for Grown-ups and Kids in Rice Fields Zones of Pegayut Waterway Streams

\begin{tabular}{lcccc}
\hline \multirow{2}{*}{$\begin{array}{c}\text { Active } \\
\text { Ingredient }\end{array}$} & \multicolumn{2}{c}{ RQ } & \multicolumn{2}{c}{$\begin{array}{c}\text { Risk Quotient } \\
\text { Criteria }\end{array}$} \\
\cline { 2 - 5 } & $\begin{array}{c}\text { (Risk Quotient ) } \\
\text { Grown- } \\
\text { ups }\end{array}$ & Children & $\begin{array}{c}\text { Grown- } \\
\text { ups }\end{array}$ & Children \\
\hline Aldicarb & 0.024 & 0.01 & Acceptable & Acceptable \\
\hline Carbaryl & 0.08 & 0.15 & Acceptable & Acceptable \\
\hline Carbofuran & 0.84 & 1.53 & Acceptable & Unacceptable \\
\hline Propoxur & 0.21 & 0.38 & Acceptable & Acceptable \\
\hline RQ Total & 1.15 & 2.07 & Unacceptable & Unacceptable \\
\hline
\end{tabular}

\section{Risk Management}

This study carried out a risk management scenario for carbofuran for kids because the $R Q$ was over 1.

Acceptable Carbofuran Concentration:

The result of the equation over, the maximum acceptable concentration of carbofuran for kids was $0.003 \mathrm{mg} / \mathrm{l}$ for 30 years

Acceptable Consumption Rate:

The result of the equation is that the maximum acceptable consumption rate of carbofuran for kids was only 0.65 liter/day. 
Acceptable Frequency of Exposure:

Based on the equation above, the frequency of safe exposure to carbofuran for kids in waterway streams during 228 days yearly.

Acceptable Time of Duration:

The result above showed that Carbofuran exposure in the waterway streams for kids weighing 15 $\mathrm{kg}$ was only allowed for 19.6 years.

Therefore, it can be concluded that children in the agricultural area of Pegayut Village can only be exposed to a maximum of $0.003 \mathrm{mg} / \mathrm{l}$ Carbofuran every day with a frequency of 228 days/year for 19.6 years.

\section{DISCUSSION}

The health risk assessment due to pesticides exposure was developed using environmental health risk analysis methods. It is a method for estimating the level of risk of a chemical in the future (30). Furthermore, it has been used as a solid basis for further decisionmaking to take necessary efforts in controlling pesticides contamination in primary water sources in Dalian, China (33). A previous study in Saudi Arabia on health risk assessment in Al-Kharj area from the pollution of groundwater due to intensive application in dried areas identified vulnerable sources and assessed the risks of pesticides exposure to public health and the environment (34).

Although the results of Aldicard, Carbaryl, Carbofuran, Profoxur, $\mathrm{pH}$, and temperature measurements in the waterway streams were within the standard limit maximum (35-36), it was not safe for community living in Pegayut Village. The active ingredient Carbamate in the river was caused by the misapplication of pesticides and washing of equipment after the application. Furthermore, organophosphates and carbamates are the active ingredients that local farmers commonly use. Based on a previous study on the risk assessment of 29 pesticides in China, carbamate is the most widely used and is detected every season in the Huangpu River basin and aquatic biota (37).

A similar study in Ecuador stated that several types of active pesticide ingredients, including carbamate, have been used in rice farming and are the leading cause of contamination in the Guayas river basin (38). Similarly, carbamate was also identified in the Tulungagung vegetable farm, and the average of farmers used more than two types (39). According to a study, the level of carbofuran detected in the Nile waterway stream was $1.6 \mu \mathrm{g} / \mathrm{l}(2)$, while carbaryl level in the River Madre de Rios, Costa Rica, has an average of $0.62 \mu \mathrm{g} / \mathrm{l}(40)$. The residue of carbofuran and carbaryl was also detected in the Feni district of Bangladesh due to contaminated aquatic ecosystems and human health effects (41). Meanwhile, the presence of several active ingredients in the river is caused by excessive use of pesticides as well as misuse during and after application, which leads to contamination of river water, groundwater, and surface water in the agricultural areas (42-43).

The dose-response assessment is the second step to examine the relationship between risk agent doses and human adverse health effects (29-30). It aims to determine the risk agents' pathways of entering the human body (30). Moreover, the dose and response assessment was carried out to determine the reference dose value of each active ingredient of carbamate. Data on the reference dose of the active ingredient carbamate is available on the IRIS website (31). Meanwhile, regular monitoring of carbamate exposure is necessary to support the estimation of health effects for the next epidemiological assessment.

Exposure assessment was carried out to determine the pesticides exposure route and calculate intake value. Moreover, pesticides are accumulated in the human body through several routes such as inhalation, ingestion, and dermal, which cause long-term and chronic effects (44). This study showed that the potential dose of aldicarb for grown-ups and kids was above the reference dosage value and the carbofuran potential dose for kids. The exposure was assessed through an ingestion route from river water that was consumed by communities living around the Pegayut farming. The result showed that pesticide exposure in the Pegayut waterway streams came from agricultural activities and several paddy mill factories in the village. The concentration of the active ingredient carbamate discovered in river water was among the variables used to calculate the potential dose or intake value. The potential dose value was affected by several variables, namely measuring carbamate levels, body weight, exposure time, and exposure time (30). A previous study showed that the potential dose below the reference dose caused acute health problems, and when it was more than the reference dose, chronic health problems occurred (45).

Although the guideline for health risk analysis in Indonesia has existed for several years, optimal implementation is not expected, especially health risk programs due to pesticides exposure in agricultural areas. Therefore, this study aims to develop a health risk analysis program due to pesticides exposure in agricultural areas and risk control strategies. In Europe, a related study on human health risk assessment was an essential part of approving active ingredients as an authority for plants protection and biocide products 
in line with pesticide legislation (46). Risk assessment predicts pesticide exposures among farmers and their families and decides preventive activities for human adverse effects and environmental contamination (24). It contributes to identifying and determining active ingredients together with current and future environmental health status, especially in children (47). Based on a study in China, children in the agricultural regions are exposed to carbamate, mainly carbofuran. Meanwhile, both prenatal and postnatal exposure to carbamate leads to neurodevelopmental effects (48). A study in Mexico also stated that exposure to organophosphorus and carbamates increased oxidative stress levels in occupationally exposed farmers (49). Therefore, early prevention efforts are required to predict the development of diseases from exposure to pesticides, especially in people living in agricultural areas.

The Risk Quotient (RQ) is the final step in the environmental health risk analysis used to determine whether the active ingredient carbamate is safe or unsafe in waterway streams for the next 30 years in Pegayut village. The result showed that misuse and misapplication of pesticides caused pollution of waterway streams used by local communities for daily needs and the $R Q$ of carbofuran was more than 1 . Therefore, risk management is needed to decrease carbofuran concentration in waterway streams and communicate to local decision-makers or risk managers. Risk characterization provides alternative management to local decision-makers or managers by minimizing carbamate exposure in waterway streams through water treatment before use. Health risk assessment due to exposure such as carbamate increases the knowledge of pesticides pollution in the environment, reduces exposure, and explores its implications for public health, including farmers, families, and communities living in the agricultural areas.

This showed that pesticides exposure is through waterway streams, and the rice consumed is not examined in this study. Therefore, it is essential to determine the concentration of active ingredients in rice to estimate the risk level in the future. This study also contributes to the early detection of diseases caused by pesticides exposure in people living in agricultural areas, especially children. However, the weakness of this study is that parameter measurements were carried out only on the active ingredient of carbamate in waterway streams, and its monitoring in water was only carried out in one season, while the organophosphate group has not been examined due to limited funds. Therefore, there is a need to examine other active ingredients, mainly organophosphate groups in both water and rice, to obtain complete information on pesticides exposure in several environmental media such as air, food, sediment, or soil.

\section{ACKNOWLEDGEMENTS}

The authors are grateful to Health Polytechnic Palembang Ministry of Health for financing this study, Head of Pegayut Village, and Pegayut Primary Health Care for encouragement.

\section{CONCLUSION}

The conclusion of this study is to provide information on the presence of the active ingredient of carbamate in waterway streams river in paddy fields area. The active ingredients of carbamate in the waterway streams were below the maximum limit. Since the carbofuran RQ (Risk Quotient) obtained was over 1, risk management needs to be carried out. The results of this study are methods of health risk analysis for carbamate exposure, which provide information for local decision-makers in managing the risk of exposure in waterway streams near agricultural areas. It is necessary to regularly monitor other parameters of the waterway stream's quality as an environmental health program at the public health center. Therefore, further study on carbamate concentrations and other pesticides in rice, air, and sediment is required.

\section{REFERENCES}

1. Liu L, Tang J, Zhong G, Zhen X, Pan X, Tian C. Spatial Distribution and Seasonal Variation of Four Current-Use Pesticides (CUPs) in Air and Surface Water of the Bohai Sea, China. Sci Total Environ. 2018;621(1):516-523. https://doi.org/10.1016/j. scitotenv.2017.11.282

2. Shalaby SEM, El-Saadany SS, Abo-Eyta AM, AbdelSatar AM, Al-Afify ADG, Abd El-Gleel WMM. Levels of Pesticide Residues in Water, Sediment, and Fish Samples Collected from Nile River in Cairo, Egypt. Environ Forensics. 2018;19(4):228-238. https:// doi.org/10.1080/15275922.2018.1519735

3. Balmer JE, Morris AD, Hung H, Jantunen L, Vorkamp $\mathrm{K}$, Rigét $\mathrm{F}$, et al. Levels and Trends of CurrentUse Pesticides (CUPs) in The Arctic: An Updated Review, 2010-2018. Emerg Contam. 2019;5(1):7088. https://doi.org/10.1016/j.emcon.2019.02.002

4. Mariyono J, Kuntariningsih A, Kompas T. Pesticide Use in Indonesian Vegetable Farming and Its Determinants. Manag Environ Qual An Int J. 2018;29(2):305-323. https://doi.org/10.1108/MEQ12-2016-0088

5. Mohammad N, Abidin EZ, How V, Praveena SM, Hashim Z. Pesticide Management Approach 
Towards Protecting the Safety and Health of Farmers in Southeast Asia. Rev Environ Health. 2018;33(2):123-134. https://doi.org/10.1515/reveh2017-0019

6. Utami RR, Geerling GW, Salami IRS, Notodarmojo $S$, Ragas AMJ. Agricultural Pesticide Use in the Upper Citarum River Basin: Basic Data for Model-Based Risk Management. E3S Web of Conferences. 2020;211(1):1-9. https://doi. org/10.1051/e3sconf/202021103009

7. Silva V, Mol HGJ, Zomer P, Tienstra M, Ritsema CJ, Geissen V. Pesticide Residues in European Agricultural Soils - A hidden Reality Unfolded. Sci Total Environ. 2019;653(1):1532-1545. https://doi. org/10.1016/j.emcon.2019.02.002

8. Joko T, Dewanti NAY, Dangiran HL. Pesticide Poisoning and the Use of Personal Protective Equipment (PPE) in Indonesian Farmers. J Environ Public Health. 2020;5379619(1):1-9. https://doi. org/10.1155/2020/5379619

9. Nguyen TM, Le NTT, Havukainen J, Hannaway DB. Pesticide Use in Vegetable Production: A Survey of Vietnamese Farmers' Knowledge. Plant Prot Sci. 2018;54(4):203-214. https://doi. org/10.17221/69/2017-PPS

10. Jiao $C$, Chen $L$, Sun $C$, Jiang $Y$, Zhai L, Liu H, et al. Evaluating National Ecological Risk of Agricultural Pesticides from 2004 to 2017 in China. Environ Pollut. 2020;259(113778):1-9. https://doi. org/10.1016/j.envpol.2019.113778

11. Gupta RC, Mukherjee IRM, Doss RB, Malik JK, Milatovic D. Chapter 35 - Organophosphates and Carbamates. In: Gupta RC, editor. Reproductive and Developmental Toxicology (Second Edition). Academic Press; 2017. p. 609-31. https://doi. org/10.1016/B978-0-12-804239-7.00035-4

12. Directorate of Fertilizers and Pesticides. Agriculture and Forestry Pesticides in 2016. Directorate General of Agricultural Infrastructure and Facilities; 2016. p. 1-905.

13. Maksuk M, Malaka T, Suheryanto S, Umayah A. Risk Quotient of Airborne Paraquat Exposure among Workers in Palm Oil Plantation. Int J Public Heal Sci. 2018;7(2):97-101. https://doi.org/10.11591/ iiphs.v7i2.11776

14. Maksuk M, Malaka T, Suheryanto S, Umayah A. Environmental Health Risk Analysis of Paraquat Exposure in Palm Oil Plantations. Int J Public Heal Sci. 2016;5(4):465-469. http://doi.org/10.11591/ iiphs.v5i4.4852

15. Samsidar A, Siddiquee S. Acetylcholinesterase (AChE) Biosensors for Determination of Carbamate Pesticides. In: Nanotechnology: Applications in Energy, Drug and Food. Springer; 2019. p. 361375. https://doi.org/10.1007/978-3-319-99602$\underline{818}$

16. Struger J, Grabuski J, Cagampan S, Sverko E, Marvin C. Occurrence and Distribution of Carbamate Pesticides and Metalaxyl in Southern Ontario Surface Waters 2007-2010. Bull Environ Contam Toxicol. 2016;96(4):423-431. https://doi. org/10.1007/s00128-015-1719-x
17. Kumar A, Margekar SL, Margekar P, Margekar V. Recent Advances in Management of Organophosphate \& Carbamate Poisoning. Indian $J$ Med Spec. 2018;9(3):154-159. https://doi. org/10.1016/j.injms.2018.06.007

18. Wang N, Wang B, Wen J, Li X, Pan L, Zhang J, et al. Types of Exposure Pesticide Poisoning in Jiangsu Province, China; The Epidemiologic Trend between 2006 and 2018. Int J Environ Res Public Health. 2019;16(14):1-8. https://doi.org/10.3390/ ijerph16142586

19. Jawale CA, Rajput $\mathrm{KH}$, Ugale BJ. Assessing the Impact of Pesticides: An Overview. Int J Life Sci. 2017;5(3):474-479. http://oaji.net/ articles/2017/736-1507309404.pdf

20. Yimaer A, Chen G, Zhang M, Zhou L, Fang X, Jiang W. Childhood Pesticide Poisoning In Zhejiang, China: A Retrospective Analysis from 2006 to 2015. BMC Public Health. 2017;17(602):1-8. https://doi. org/10.1186/s12889-017-4505-3

21. Adegun AO, Akinnifesi $A$, Thompson A, Ololade IA, Olonisakin A, Omodara $O$, et al. Cabamates and Pyrethroid Pesticide Residues in Fish from Owena River, Ondo State, Nigeria and their Health Risk Evaluation. Sch Int J Chem Mater Sci. 2020;3(4):41-47. https://saudijournals.com/ journal-details/sijcms/62/505

22. Musa M, Buwono NR, Iman MN, Ayuning SW, Lusiana ED. Pesticides in Kalisat River: Water and Sediment Assessment. Aquac Aquarium, Conserv Legis. 2019;12(5):1806-1813. http://www.bioflux. com.ro/home/volume-12-5-2019/

23. Buwono NR, Gultom T, Ayuning SW, Supriatna S. Bioaccumulation of Pesticide Residues in Gastropod Communities at Kalisat River, Malang Regency. Depik. 2019;8(3):167-175. http://10.0.51.114/ depik.8.3.14368

24. Soudani N, Belhamra M, Ugya AY, Patel N, Carretta L, Cardinali A, et al. Environmental RiskAssessment of Pesticide Use in Algerian Agriculture. J Appl Biol Biotechnol. 2020;8(5):36-47. https://doi. org/10.7324/JABB.2020.80505

25. Škrbić BD, Kadokami K, Antić I. Survey on the Micro-Pollutants Presence in Surface Water System of Northern Serbia and Environmental and Health Risk Assessment. Environ Res. 2018;166(1):13040. https://doi.org/10.1016/j.envres.2018.05.034

26. Ministry of Health Republic Indonesia. Guidelines for Environmental Health Risk Analysis. Jakarta: Directorate General of Disease Prevention and Control of Ministry of Health Republic Indonesia. 2012.

27. Hadi A. Prinsip Pengelolaan Pengambilan Sampel Lingkungan. Jakarta: Gramedia Pustaka Utama; 2005.

28. Louvar JF, Louvar BD. Health and Environmental Risk Analysis. Vol. 2. United States: Prentice Hall; 1998.

29. EnHealth. Environmental Health Risk Assessment. Guidelines for Assessing Human Health Risks from Environmental Hazards. Canberra: Department of 
Health and Ageing of Australia; 2002. https://www. health.gov.aul

30. World Health Organization. Principles for Modelling Dose-Response for the Risk Assessment of Chemicals. Geneva: World Health Organization;2009. https://apps.who.int/iris/ handle/10665/43940

31. United States Environmental Protection Agency. IRIS Assessments. United States: United States Environmental Protection Agency; 2017. https:// iris.epa.gov/AtoZ/?list type=alpha

32. Kolluru RV, Bartell SM, Pitblado RM, Stricoff RS. Risk Assessment and Management Handbook for Environmental, Health, and Safety Professionals. New York: McGraw-Hill Inc; 1998.

33. Dong W, Zhang Y, Quan X. Health Risk Assessment of Heavy Metals and Pesticides: A Case Study in The Main Drinking Water Source in Dalian, China. Chemosphere. 2020;242:125113. https://doi. org/10.1016/j.chemosphere.2019.125113

34. El Alfy M, Faraj T. Spatial Distribution and Health Risk Assessment for Groundwater Contamination from Intensive Pesticide Use in Arid Areas. Environ Geochem Health. 2017;39(1):231-253. https://doi. org/10.1007/s10653-016-9825-1

35. Ministry of Health of Republic Indonesia. Regulation of Ministry of Health of Republic Indonesia No.32/ MENKES/2017 about Environmental Health Quality Standards and Water Health Requirements for Sanitary Hygiene, Swimming Pools, Solus Per Aqua, and Public Baths. Jakarta: Ministry of Health of Republic Indonesia; 2017. https://peraturan. bpk.go.id/Home/Details/112092/permenkes-no-32tahun-2017

36. South Sumatera Governor. Regulation of South Sumatera Governor No.16/2005 About Water Designation and River Water Quality Standards. Palembang: South Sumatera Governor; 2005.

37. Xu L, Granger C, Dong H, Mao Y, Duan S, Li J, et al. Occurrences of 29 Pesticides in the Huangpu River, China: Highest Ecological Risk Identified in Shanghai Metropolitan Area. Chemosphere. 2020;251(126411):1-11. https://doi.org/10.1016/j. chemosphere.2020.126411

38. Deknock A, De Troyer $N$, Houbraken $M$, Dominguez-Granda L, Nolivos I, Van Echelpoel W, et al. Distribution of Agricultural Pesticides in The Freshwater Environment of The Guayas River Basin (Ecuador). Sci Total Environ. 2019;646(1):996-1008. https://doi.org/10.1016/j. scitotenv.2018.07.185

39. Wismaningsih ER, Oktaviasari DI. Pesticide Identification and Personal Protective Equipment (PPE) Use of Spraying Farmer in Ngantru Tulungagung District. J Wiyata Penelit Sains dan Kesehat. 2017;3(1):100-105. http://ojs.iik.ac.id/ index.php/wiyata/article/view/77
40. Rämö RA, van den Brink PJ, Ruepert C, Castillo LE, Gunnarsson JS. Environmental Risk Assessment of Pesticides in the River Madre de Dios, Costa Rica Using PERPEST, SSD, and msPAF Models. Environ Sci Pollut Res. 2018;25(14):13254-13269. https://doi.org/10.1007/s11356-016-7375-9

41. Bhuiyan MAH, Rahman MH, Uddin MA, Chowdhury MAZ, Rahman MA, Saha BB, et al. Contamination of Pond and Canal Water by Residues of Organophosphorus and Carbamate Pesticides in Feni District, Bangladesh. Environ Sustain. 2021;4(1):191-197. $\quad$ https://doi.org/10.1007/ s42398-021-00161-1

42. Sharifzadeh MS, Abdollahzadeh G, Damalas CA, Rezaei R, Ahmadyousefi M. Determinants of Pesticide Safety Behavior Among Iranian Rice Farmers. Sci TotalEnviron. 2019;651(1):2953-2960. https://doi.org/10.1016/j.scitotenv.2018.10.179

43. Sun S, Hu R, Zhang C, Shi G. Do Farmers Misuse Pesticides in Crop Production in China? Evidence from A Farm Household Survey. Pest Manag Sci. 2019;75(8):2133-2141. https://doi.org/10.1002/ ps.5332

44. Damalas CA, Koutroubas SD. Farmers' Exposure to Pesticides: Toxicity Types and Ways of Prevention. Toxics. 2016;4(1):1-10. https://www. mdpi.com/2305-6304/4/1/1

45. Mekonen S, Argaw R, Simanesew A, Houbraken $M$, Senaeve D, Ambelu A, et al. Pesticide Residues in Drinking Water and Associated Risk to Consumers in Ethiopia. Chemosphere. 2016;162(1):252-260. https://doi.org/10.1016/j. chemosphere.2016.07.096

46. Kaltenhäuser $\mathrm{J}$, Kneuer $\mathrm{C}$, Marx-Stoelting $\mathrm{P}$, Niemann L, Schubert J, Stein B, et al. Relevance and Reliability of Experimental Data in Human Health Risk Assessment of Pesticides. Regul Toxicol Pharmacol. 2017;88(1):227-237. https:// doi.org/10.1016/j.yrtph.2017.06.010

47. Daam MA, Chelinho S, Niemeyer JC, Owojori OJ, De Silva PMCS, Sousa JP, et al. Environmental Risk Assessment of Pesticides in Tropical Terrestrial Ecosystems: Test Procedures, Current Status and Future Perspectives. Ecotoxicol Environ Saf. 2019;181(1):534-547. https://doi.org/10.1016/j. ecoenv.2019.06.038

48. Zhang J, Guo J, Wu C, Qi X, Jiang S, Lu D, et al. Exposure to Carbamate and Neurodevelopment in Children: Evidence from the SMBCS Cohort in China. Environ Res. 2019;177(108590):1-7. https:// doi.org/10.1016/j.envres.2019.108590

49. Salazar-Flores J, Pacheco-Moisés FP, Ortiz GG, Torres-Jasso JH, Romero-Rentería O, BrionesTorres AL, et al. Occupational Exposure to Organophosphorus and Carbamates in Farmers in La Cienega, Jalisco, Mexico: Oxidative Stress and Membrane Fluidity Markers. J Occup Med Toxicol. 2020;15(32):1-11. https://doi.org/10.1186/s12995020-00283-y 